\title{
The Basic Characteristics of Adult Learners
}

\author{
Yieusef Lauouim
}

\begin{abstract}
Adults learning is concerned with grown-up students who are no longer children, so this category of learners needs specific treatment and methods to meet their state of affairs, needs, interests, and expectations. Thereby, this paper provides the reader, adult educators in particular, with some methodological and theoretical framework to consider before taking on the instruction of adults.
\end{abstract}

Keywords: Adult, Learner, strategy, approach

\section{Introduction}

Adult learners are different from younger learners, or kids on several grounds. Adults are characterized by many principles such as their set learning goals, self-direction, accountability, clear objectives, and prior knowledge and experience (Florez \& Burt, 2001, p. 1). This implies that adult learners are usually driven by certain objectives that allow them to decide how to handle their learning trajectory, until achieving their aims. Teachers, to this effect, need to provide the right content and methods that suit the needs and the learning principles of adults (ibid).

\section{1) Adults' preferred approach}

Adults would likely feel stifled towards the teacher-centered approach because they believe that they have their own cognitive potential to build knowledge through problemsolving, task-based learning, discussion, discovery, projectbased learning and others (Okojie \& Boulder, 2020, p. 21). This apprizes that instructors need to use dynamic and collaborative methods which go in line with the interests and learning strategies or goals of grown learners. The educators of adults need to sidestep the exaggerated reliance on exposition methods and linearity in communication. On this, finding balance between the expository and the hypothetical approaches is an important fact. The expository approach refers to teachers' centered role to convey contents and install knowledge, while the hypothetical approach renders learners more active and cooperative in the learning and teaching process (Rogers \& Horrocks, 2010, p. 241). This means that teachers ought to adapt the learning contents they have in hands to the previously mentioned idiosyncrasies of adult learners so that students become self-confident and feel that they are essential entities within the programs they undergo, without being morally offended, undermined, marginalized, or bored.

\section{2) Effective language acquisition}

Adults can acquire language appropriately when instructors underpin their classes with the approaches that are suitable for adult learners. The insights of Brown, 2001 and Lightbown, 2000, do superbly enough proffer some suggestions that seem adequate for adult learners to process and internalize the information relating to language (Florez \& Burt, 2001, p. 2). Their recommendations propose that instructors should use natural and meaningful communication in the target language (Natural Approach), help students use language as a tool (Functional-Notional Approach), incorporate and integrate skills that yield balance between form, meaning and use, put students in challenging situations, manage the class well to maintain motivation and excitement, focus on students' comprehension after receiving new skills, and be eclectic when selecting the optimal teaching theories for adults (ibid 2-4).

\section{3) Teaching multicultural groups}

Needless to say, we are living in a small village, so truisms of immigration, migration, and mobility have become familiar things nowadays. This fact is also conducive to the growth of multicultural communities where schools receive students of different mores and descents. Hence, teaching in multicultural contexts has become irrevocable, and thus knowing how to manage such settings is in turn an indispensable skill.

In diversified classrooms, teachers need to grasp the cultural background and the linguistic differences of students because adults enter schools with different language proficiency; their knowledge is disparate; their financial and social statuses can be dissimilar; and their expectations are not the same (Short \& Fitzsimmons, 2007, p. 10).

Terry L. Shepherd and Diana Linn elaborate that the notion equitability becomes the key factor when teaching multicultural classrooms (Shepherd L. \& Linn, 2015, p. 25). In reference to equitable treatment, they illustrate that teachers need to be aware of the cultural differences in their classrooms and how culture affects one's behavior. Teachers, in this vein, are required to remove uncertainty with students by understanding some cultural subtleties belonging to divergent life aspects such as sports, music, food, individualism, and collectivism (ibid 26).

In this frame, Shepherd and Linn allude to three principles which remove the cultural fences between teachers and students who hold different cultural backgrounds. The first of which is called 'the broader context'. This principle entails that teachers have to rationally identify the cultural behavior of their students and the impulse behind it. For example, eye contact between teachers and students in America is considered a decent demeanor whereas in some Hispanic communities, eye contact is perceived as an inappropriate deportment (Shepherd L. \& Linn, 2015, p. 27). Hence, our body language is a cultural emblem, and there are hundreds of examples that can emerge in this context. The second principle is relating to the implementation of pertinent strategies to manage multicultural classes. Teachers, in this regard, need to use strategies such as selfreflection to know how to contain the cultural differences between their culture and students' culture and how to respond to the cultural needs of students (ibid 28). The third principle is bound to caring. By caring, teachers propel 
students to mingle in the classroom and find out that cultural differences do not bereft them of coexistence and positive exchange, instead, students digest that cultural dissimilarities serve as mosaics that make the classroom a glamorous and multicolored place (ibid 29).

What is more, Florez and Burt (2001) shed light on the common threads between culture and language, and reveal that dealing with culture is conducive to positive acquisition and learning in the classroom. They emphasize that when students start to learn a new language, they simultaneously become pulled into the culture of that language (Florez \& Burt, 2001, p. 4). Be that as it may, teachers are supposed to be savvy enough to facilitate this cultural vicissitude to students and avoid judgmental cultural comparisons and stereotypes. That is, cultures are different not because one is better than the other, but they are so because each culture has its unique significance and charm. When students look at culture this way, matters of tension and uncertainty relinquish seemingly. Besides, in some discussion activities, many topics can be deemed taboo or disrespectful subjects for some students, so teachers ought to be watchful of such divergence and choose neutral themes (ibid 4-5).

Culture and education are currently nested and interrelated concepts. This is why cross-cultural awareness is considered one of the incumbent skills in education in the $21^{\text {st }}$ century. Our future graduates are supposed to work in different cultural settings. Ergo, they need to be culturally cognizant and prepared to communicate with people from different backgrounds, create or bring innovative ideas, and solve problems (Trilling \& Fadel, 2009, p. 81).

\section{4) Adult learning theories}

The TEAL team ${ }^{1}$ did an impeccable work in 2011 that caters to some optimal theories to teach adults. The first of which is the notion of andragogy, which was developed by Malcolm Knowles in 1980 (TEAL Team, 2011, p.1). Andragogy is different from pedagogy. The former is about the art and science of helping students learn, while the second refers to the science of teaching students (ibid). By fostering the andragogy concept, teachers should incline to autonomous learning, cooperative learning, students' differences and needs, problem-solving situations, and the application of the items learnt by doing (ibid). The second theory is selfdirection learning; this theory advocates students to be assigned to do tasks independently. Independence here comprises the activities done outside the classroom, and the role of teachers is to orient, motivate, and help students carry on the tasks they do and the materials they choose to build their knowledge. The self-direction perspective is quite helpful to ingrain responsibility and accountability in students (ibid 1-2). The third theory is called transformational learning. In this concept, students learn in order to understand themselves and the world better. It helps students analyze and discuss phenomena open-mindedly and through the exchange of views and perspectives. Teachers, to this effect, can allow collaboration between harmonious groups, the exploration of alternative perspectives tied to any topic, support logic, and expose students to the life experiences of others (ibid 2-3). The fourth and final theory is what experts call bringing theory into practice. In this theory, students encounter prompts that ask them to react practically. Students do not only confine to the observation of instructions, but they become part of it by being mandated to do, perform, and act instantaneously (ibid). In a word, these concepts in adult learning are prominent to supply students with a plethora of competences like problemsolving, self-direction, reliability, flexibility, and adaptability.

\section{Conclusion}

The sprinkled insights in this article reaffirm that studentcentered learning is fittingly enough for adults. Adults are no longer children; they need to be recognized as 'co-creators' of learning equally with teachers or even more. This means that adult educators are highly encouraged to maximize the use of the theories, methods, and strategies that give the opportunities for learners to be autonomous and have active roles inside and outside the classroom.

\section{References}

[1] Florez, M.C., \& Burt, M. (2001). Beginning to work with adult English language learners: Some considerations. Retrieved March 17, 2021, from https://eric.ed.gov/?id=ED458837

[2] Okojie, M., \& Boulder, T. C. (2020). Foundations of Adult Education, Learning characteristics, and Instructional Strategies. In M. Okojie, \& T. C. Boulder, Handbook of Research on Adult Learning in Higher Education (pp. 1-33). Hershey: IGI Global .

[3] Rogers, A., \& Horrocks, N. (2010). Teaching Adults (4th ed.). London: Open University Press.

[4] Short, D. J., \& Fitzsimmons, S. (2007). Double the Work. New York: Alliance for Excellent Education.

[5] TEAL Team. (2011). Adult Learning Theories. Retrieved March 18, 2021, from https://lincs.ed.gov/state-resources/federalinitiatives/teal

[6] Terry, S. L., \& Linn, D. (2015). Behavior and Classroom Management in the Multicultural Classroom. London : SAGE.

[7] Trilling, B., \& Fadel, C. (2009). 21st Century Skills: Learning for Life in Our Times. San Francisco: JosseyBass.

\footnotetext{
${ }^{1}$ Teaching Excellence in Adults Literacy: A project held by the American Institutes for Research.
} 